\title{
DEVELOPMENT OF LEADERSHIP AND COMMUNICATION SKILL MODEL ON MIDWIFERY STUDENTS IN PHYSIOLOGICAL DELIVERY PRACTICE
}

\author{
Sri Utami, Rekawati Susilaningrum, Susilorini Susilorini \\ Poltekkes Kemenkes Surabaya, Jl. Pucang Jajar Tengah no. 56 Surabaya, 60282 \\ Email: bu.sri.utami67@gmail.com
}

\begin{abstract}
Introduction: Currently there is a tendency for students only prioritising hard skills without improving their soft skills. This is indicated by the negative attitudes and actions such as delay task submission, bad time management, and a lack of commitment towards a task. The purpose of this research is to find out the model of leadership skill development and communication skill of the vocational Midwifery course. Methods: This study consists of two stages. The research type was observational and explanatory. The first stage used a cross-sectional design and the second stage was quasi-experimental. The subjects of the study for the first stage was 130 respondents, calculated by "rule of the thumb" and by purposive sampling. The second stage consisted of 38 respondents taken by random sampling. The exogenous variables are motivation, self-leadership strategies, job satisfaction, psychological empowerment, self-efficacy, and task commitment. The endogenous variables are leadership skill and communication skills. In the first stage, the data were analysed using PLS and the second stage used a Wilcoxon test with $\alpha=0,05$. Results: The variables of motivation, self-leadership and job satisfaction could improve communication skills. In stage 2 (after training), all of the variables increased significantly with $\mathrm{p}$ $<0,05$. Conclusions: Training using the self-leadership module can improve the ability of motivation, self-leadership strategies, job satisfaction, self-efficacy, psychological empowerment, task commitment, communication and student leadership skills.
\end{abstract}

Keywords: communication skills, motivation, self-leadership

\section{INTRODUCTION}

Education is a major factor in the personal development of humans. Several studies related to soft skills show that Grade Point Average (GPA) can only describe the quality of a person in the cognitive aspect and cannot indicate a person's qualifications in relation to soft skills, also called social skills (Puliam, 2008). Harvard University revealed that the success of one's career is $80 \%$ determined by soft skills and only about $20 \%$ determined by hard skills. The survey of the National Association of College and Employers (NACE), USA 2002 in (Wanarto, Guntur Budi., 2014) taken by 457 leaders in America showed that out of about 20 important qualities possessed by successful people, the result was mostly soft skills, and only two of them considered it to be hard skills (Kuswara, 2008). Looking at the research results above, demanding education including in relation to midwifery to prepare graduates will mean that they not only have academic achievements with a high GPA score but also have skills ready to use in the world of work.

Besides mastering the academic and technical skills of midwifery, midwifery students must also have communication and leadership skills. The importance of soft skill mastery when the midwife enters the world of work should use the midwifery education institution to design a soft skills development program as a means of building work ethics with the students that is included in the direct learning within the community (Suryani, 2015).

Students, as the next generation of the nation, must have the ability, skills and a personality that is strong and polite. Soft skills are skills that can form a formidable personality. The more soft skills that a person possesses, it is expected that they will have a stronger personality when facing the challenges of the learning process on campus, work challenges, and other life challenges. Soft skills are a person's skill in dealing with others. College graduates expect that the workforce should have positive soft skills, a strong attitude, are honest, passionate, able to work together, polite in communicating, good at negotiating, have a high work motivation, are creative and adaptable, and so are able to work intensively.

"The Lessons from The Top" written by Thomas J. Neff and James M. Citrin (1999) in (Wirawan, 2013) says that the key to success is determined by $90 \%$ soft skills and only $10 \%$ is determined by hard skills. The Ministry of National Education's study in 2009 states that one's success in education is $85 \%$ determined by soft skills.

The Sutomo Midwifery major is one of the educational institutions that implement an educational program with the vision of producing competent midwives who are independent and are able to compete in the 
global era, by upholding values and professional ethics. To realise that, the students are required to have both hard skills and soft skills that can be demonstrated by the abilities of the students in relation to leadership skills, communication skills, the ability to interact, to not procrastinate on tasks and many other things. The most recent fact is that the majority of students still limited with just the hard skills that are shown by their academic achievements, with less care given to their soft skills. Observations have found recently that students often $(65 \%)$ delay on their task completion, and that $70 \%$ of students tend to learn only when faced with exams have bad time management and a lack of commitment in performing their duties as a student.

Various steps can be undertaken to improve soft skills such as leadership skills and student communication skills in the practice of physiological midwifery care. The novelty of this research is to create a development model of self-leadership strategies to improve leadership and communication skills. From the previous research, the ability of self-leadership is an important variable in relation to performed improvement measured in quantity. In this research, it is assumed that there are motivational variables that can improve the ability of self-leadership strategies as an effort to improve various positive aspects that impact on the increase of students' soft skills, especially leadership skill and communication skills in the physiological delivery practice (Wanarto, Guntur Budi., 2014).

\section{MATERIALS AND METHODS}

This research type is observational and explanatory. The first stage used a crosssectional design and the second stage used a quasi-experimental approach. The subjects of the study were vocational students of the Dr Sutomo Midwifery course on Surabaya; the first stage consisted of 130 respondents taken by purposive sampling. The second stage sample was 38 respondents taken by random sampling. The exogenous variables were motivation, self-leadership strategies, job satisfaction, psychological empowerment, selfefficacy, and task commitment, while the endogenous variable was communication skill.
The instrument used was a questionnaire. The data collection procedure in the first stage began with an explanation of the research objectives and the willingness to become a respondent as evidenced by the provision of informed consent. Furthermore, the respondents were given a questionnaire to explore data about all of the variables. The second stage began with the giving of informed consent. Before the students performed clinical practice, a pre-test on all of the variables was conducted. This was followed by two days training in selfleadership strategies. The control group was not given any training. Both groups then performed physiological midwifery care clinical practice for 1.5 months. After 1.5 months, both groups performed a post-test. The further data obtained was analysed descriptively and inferentially; the first stage using PLS and the second stage using a Wilcoxon test with value $\alpha=0,05$.

\section{RESULTS}

\section{The First Stage Results: Analysis of the Structural Models (Inner Model)}

In the structural model analysis, the effect of the exogenous factors on the endogenous factors was tested. The reference value used was that if the T-statistical value of the processing was greater than the T-table value, then it was concluded that the exogenous factors have a significant effect on the endogenous factors. Error tolerance $(\alpha)=$ $5 \%$ and total data 130 then the value of T-table $=\mathrm{T}_{(\mathrm{df}=\mathrm{n}-1 ; \alpha / 2)}=\mathrm{T}_{(129 ; 0,025)}=1,96$. The results of the significance test are described in the following table.

Table1 shows that each exogenous variable has a significant effect on an endogenous variable, except for the job satisfaction variable and leadership skill, task commitment and leadership skill, psychological empowerment and communication skill, psychological empowerment and leadership skill, selfefficacy and communication skill and selfefficacy and leadership skills. Furthermore, the insignificant relationships were omitted. The final model was formed from the new $\mathrm{T}$ statistics value, and the details are in the following table 1 . 
Table 1. T-Test Result of the Exogenous Latent Variable to the Endogenous variables and Line Coefficient Parameters in the Early Structural Model (Inner Model)

\begin{tabular}{|c|c|c|c|c|c|}
\hline No & Line & $\begin{array}{c}\text { Original } \\
\text { Sample } \\
\text { (O) }\end{array}$ & $\begin{array}{l}\text { T Statistics } \\
(\mid \text { O/STERR } \mid)\end{array}$ & $\begin{array}{c}\text { T } \\
\text { Tabel }\end{array}$ & Information \\
\hline 1 & $\begin{array}{l}\text { (X1) Motivation } \rightarrow(X 2) \text { Self leadership } \\
\text { strategies }\end{array}$ & 0.566 & 21.684 & 1,96 & Significant \\
\hline 2 & $\begin{array}{l}\text { (X1) Motivation } \rightarrow(X 3) \text { Psychological } \\
\text { empowerment }\end{array}$ & 0.805 & 36.230 & 1,96 & Significant \\
\hline 3 & (X1) Motivation $\rightarrow(X 4)$ Job Satisfaction & 0.759 & 31.692 & 1,96 & Significant \\
\hline 4 & (X1) Motivation $\rightarrow$ (X5) Self efficacy & 0.588 & 15.661 & 1,96 & Significant \\
\hline 5 & (X1) Motivation $\rightarrow(X 6)$ Task commitment & 0.261 & 6.106 & 1,96 & Significant \\
\hline 6 & (X1) Motivation $\rightarrow$ (Y1) Communication skill & 0.274 & 3.334 & 1,96 & Significant \\
\hline 7 & (X1) Motivation $\rightarrow(Y 2)$ Leadership skill & 0.711 & 11.212 & 1,96 & Significant \\
\hline 8 & (X2) Self leadership $\rightarrow(X 3)$ Psychological & 0.133 & 5.001 & 1,96 & Significant \\
\hline 9 & $\begin{array}{l}\text { (X2) Self leadership } \rightarrow(X 4) \text { Job } \\
\text { Satisfaaction }\end{array}$ & 0.231 & 7.475 & 1,96 & Significant \\
\hline 10 & $(X 2)$ Self leadership $\rightarrow(X 5)$ Self efficacy & 0.214 & 4.544 & 1,96 & Significant \\
\hline 11 & $\begin{array}{l}\text { (X2) Self leadership } \rightarrow(X 6) \text { Task } \\
\text { commitment }\end{array}$ & 0.137 & 6.670 & 1,96 & Significant \\
\hline 12 & $\begin{array}{l}\text { (X2) Self leadership } \rightarrow(Y 1) \text { Communication } \\
\text { skill }\end{array}$ & 0.173 & 4.174 & 1,96 & Significant \\
\hline 13 & (X2) Self leadership $\rightarrow(Y 2)$ Leadership skill & 0.337 & 7.396 & 1,96 & Significant \\
\hline 14 & $\begin{array}{l}\text { (X3) Psychological } \rightarrow(X 6) \text { Task } \\
\text { commitment }\end{array}$ & 0.135 & 4.109 & 1,96 & Significant \\
\hline 15.. & $\begin{array}{l}\text { (X3) Psychological } \rightarrow(Y 1) \text { Communication } \\
\text { skill }\end{array}$ & -0.020 & 0.477 & 1,96 & $\begin{array}{c}\text { Not } \\
\text { Significant }\end{array}$ \\
\hline 16.. & (X3) Psychological $\rightarrow$ (Y2) Leadership skill & -0.053 & 0.938 & 1,96 & $\begin{array}{l}\text { Not } \\
\text { Significant }\end{array}$ \\
\hline 17 & $\begin{array}{l}(X 4) \text { Job Satisfaaction } \rightarrow \text { X6) Task } \\
\text { commitment }\end{array}$ & 0.306 & 6.224 & 1,96 & Significant \\
\hline 18 & $\begin{array}{l}\text { X4) Job Satisfaaction } \rightarrow(Y 1) \\
\text { Communication skill }\end{array}$ & 0.297 & 4.808 & 1,96 & Significant \\
\hline 19 & $\begin{array}{l}\text { (X4) Job Satisfaaction } \rightarrow(Y 2) \text { Leadership } \\
\text { skill }\end{array}$ & -0.060 & 0.600 & 1,96 & $\begin{array}{c}\text { Not } \\
\text { Significant }\end{array}$ \\
\hline 20 & (X5) Self-efficacy $\rightarrow$ X6) Task commitment & 0.217 & 6.824 & 1,96 & Significant \\
\hline $21 .$. & $\begin{array}{l}\text { (X5) Self-efficacy } \rightarrow(\text { Y1) Communication } \\
\text { skill }\end{array}$ & 0.009 & 0.252 & 1,96 & $\begin{array}{c}\text { Not } \\
\text { Significant }\end{array}$ \\
\hline 22. & (X5) Self-efficacy $\rightarrow$ (Y2) Leadership skill & -0.033 & 0.565 & 1,96 & $\begin{array}{l}\text { Not } \\
\text { Significant }\end{array}$ \\
\hline 23 & $\begin{array}{l}\text { (X6) Task commitment } \rightarrow(Y 1) \\
\text { Communication skill }\end{array}$ & 0.244 & 2.968 & 1,96 & Significant \\
\hline 24 & $\begin{array}{l}\text { (X6) Task commitment } \rightarrow(Y 2) \text { Leadership } \\
\text { skill }\end{array}$ & -0.075 & 0.630 & 1,96 & $\begin{array}{l}\text { Not } \\
\text { Significant }\end{array}$ \\
\hline
\end{tabular}


Tabel 2. T-Test Result of the Exogenous Latent Variable to the Endogenous variables and Line Coefficient Parameters in the Finale Structural Model (Inner Model)

\begin{tabular}{|c|c|c|c|c|c|}
\hline No & Line & $\begin{array}{l}\text { Original } \\
\text { Sample }(0)\end{array}$ & $\begin{array}{l}\text { T Statistics } \\
(\mid \mathbf{O} / \text { STERR } \mid)\end{array}$ & $\begin{array}{c}\text { T } \\
\text { Table }\end{array}$ & Information \\
\hline 1 & $\begin{array}{l}\text { (X1) Motivation } \rightarrow(X 2) \text { Self leadership } \\
\text { strategies }\end{array}$ & 0.566 & 23.108 & 1,96 & Significant \\
\hline 2 & $\begin{array}{l}\text { (X1) Motivation } \rightarrow \text { (X3) Psychological } \\
\text { empowerment }\end{array}$ & 0.805 & 38.621 & 1,96 & Significant \\
\hline 3 & (X1) Motivation $\rightarrow$ (X4) Job Satisfaction & 0.759 & 29.006 & 1,96 & Significant \\
\hline 4 & (X1) Motivation $\rightarrow$ (X5) Self efficacy & 0.588 & 14.551 & 1,96 & Significant \\
\hline 5 & $(X 1)$ Motivation $\rightarrow(X 6)$ Task commitment & 0.262 & 6.335 & 1,96 & Significant \\
\hline 6 & (XI) Motivation $\rightarrow$ (YI) Communication skill & 0.264 & 3.898 & 1,96 & Significant \\
\hline 7 & (X1) Motivation $\rightarrow$ (Y2) Leadership skill & 0.549 & 19.940 & 1,96 & Significant \\
\hline 8 & (X2) Self leadership $\rightarrow(X 3)$ Psychological & 0.133 & 5.627 & 1,96 & Significant \\
\hline 9 & $\begin{array}{l}(X 2) \text { Self leadership } \rightarrow(X 4) \text { Job } \\
\text { Satisfaaction }\end{array}$ & 0.231 & 6.879 & 1,96 & Significant \\
\hline 10 & $(X 2)$ Self leadership $\rightarrow(X 5)$ Self efficacy & 0.214 & 4.499 & 1,96 & Significant \\
\hline 11 & $\begin{array}{l}\text { (X2) Self leadership } \rightarrow(X 6) \text { Task } \\
\text { commitment }\end{array}$ & 0.136 & 5.954 & 1,96 & Significant \\
\hline 12 & $\begin{array}{l}\text { (X2) Self leadership } \rightarrow(Y 1) \text { Communication } \\
\text { skill }\end{array}$ & 0.172 & 4.180 & 1,96 & Significant \\
\hline 13 & (X2) Self leadership $\rightarrow(Y 2)$ Leadership skill & 0.288 & 7.249 & 1,96 & Significant \\
\hline 14 & $\begin{array}{l}\text { (X3) Psychological } \rightarrow(X 6) \text { Task } \\
\text { commitment }\end{array}$ & 0.135 & 4.103 & 1,96 & Significant \\
\hline 15 & $\begin{array}{l}\text { (X4) Job Satisfaaction } \rightarrow \text { X6) Task } \\
\text { commitment }\end{array}$ & 0.306 & 6.485 & 1,96 & Significant \\
\hline 16 & $\begin{array}{l}\text { X4) Job Satisfaaction } \rightarrow(Y 1) \\
\text { Communication skill }\end{array}$ & 0.296 & 4.427 & 1,96 & Significant \\
\hline 17 & (X5) Self-efficacy $\rightarrow$ X6) Task commitment & 0.217 & 7.514 & 1,96 & Significant \\
\hline 18 & $\begin{array}{l}(X 6) \text { Task commitment } \rightarrow(Y 1) \\
\text { Communication skill }\end{array}$ & 0.245 & 2.750 & 1,96 & Significant \\
\hline
\end{tabular}




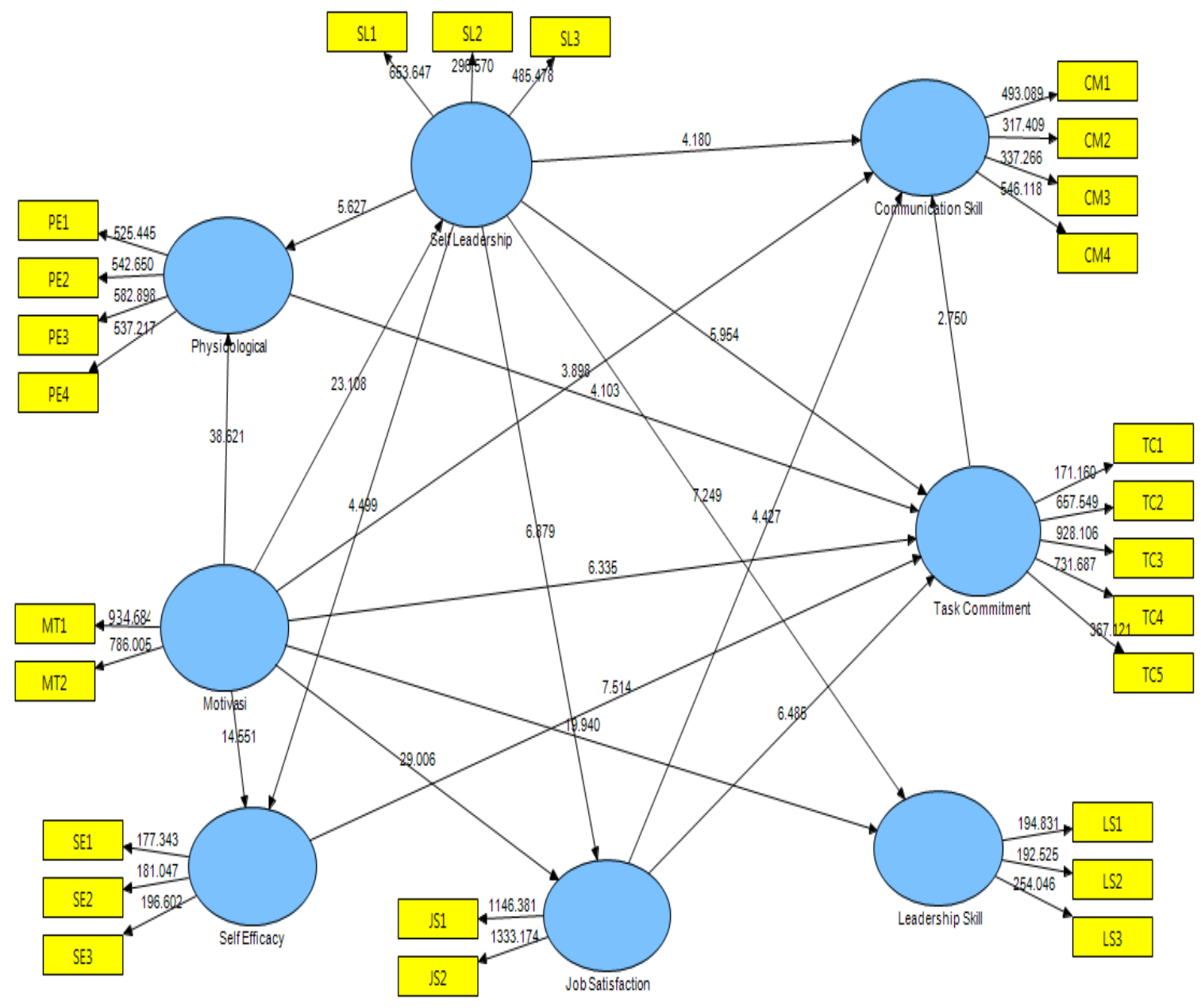

Figure 1. Finale Inner Model

\section{Goodness of Fit Index (GoF)}

The last one was to found to have the value of Goodness of Fit (GoF). In contrast to CBSEM, for GoF, the values in PLS-SEM must be searched manually. The formula is:

$$
G o F=\sqrt{\overline{A V E}} \times \overline{R^{2}} \text {........Tenenhaus (2004) }
$$

The calculation of the average AVE is 0.952511 , while the average R2 is 0.676291, so the value of $\mathrm{GoF}$ is 0.802605

According to Tenenhaus (2004), GoF small value $=0.1$, GoF medium $=0.25$ and large $\mathrm{GoF}=0.38$. Since the $\mathrm{GoF}$ value in this study was 0.802605 , the GoF value was large.

\section{The Second Stage Statistical Analysis Result}

In the second stage, the data were analysed using the Wilcoxon Statistics Test, and the results obtained are shown in Table 3. From these results, it indicates that the training given to the students about the development of self-leadership capabilities based on student motivation can improve the various positive aspects that can support the implementation of the learning process, especially the clinical practice of physiological midwifery care.

\section{DISCUSSION}

The development of self-leadership skills and the student skill model explains that motivation can improve the students' selfleadership strategies in the clinical practice of physiological midwifery care. This is in accordance with (McCanse, 1991) in Wirawan (2013) which stated that motivation is an important element in leadership. Wirawan (2013) explained that motivation plays an important role in leadership, which will encourage individual motives to act. Without motivation, people will not act, move and work well for themselves or for the organisation. High and low individual motivation determines high level of effort and a variety of individual behaviours. Motivation can improve the students' job satisfaction in 
Table 3. Results of the Pre- and Post-Data Analysis Training of Self Leadership Capability Development In Students of Midwifery in Sutomo Surabaya

\begin{tabular}{|c|c|c|c|c|c|c|c|c|c|c|c|}
\hline \multirow{2}{*}{$\begin{array}{l}\mathbf{N} \\
\mathbf{0}\end{array}$} & \multirow{2}{*}{ Variable } & \multicolumn{4}{|c|}{ Pre } & \multicolumn{4}{|c|}{ Post } & \multirow[b]{2}{*}{$\mathbf{p}$} & \multirow[b]{2}{*}{ Inf } \\
\hline & & Min & Max & Mean & \pm SD & Min & Max & Mean & \pm SD & & \\
\hline 1 & Motivation & 1.10 & 2.30 & 1.39 &.$\overline{3} 7$ & 2.80 & 3.70 & 3.07 &.$\overline{19}$ & 0,00 & sign \\
\hline 2. & Self leadership & 1.06 & 2.25 & 1.33 & .39 & 1.95 & 3.63 & 2.88 & .34 & 0,00 & sign \\
\hline 3. & Job satisfaaction & 2.00 & 3.18 & 2.26 & .39 & 2.18 & 3.53 & 2.73 & .35 & 0,00 & sign \\
\hline 4. & $\begin{array}{l}\text { Psychological } \\
\text { empowerment }\end{array}$ & 1.08 & 2.42 & 1.43 & .42 & 2.42 & 3.58 & 2.89 & .29 & 0,00 & sign \\
\hline 5. & Self efficacy & $\begin{array}{c}128 \\
0\end{array}$ & $\begin{array}{c}135 \\
0\end{array}$ & 1301.8 & 19.29 & $\begin{array}{c}107 \\
0\end{array}$ & $\begin{array}{c}164 \\
0\end{array}$ & 1397.9 & 133.4 & 0,01 & sign \\
\hline 6. & $\begin{array}{l}\text { Task } \\
\text { commitment }\end{array}$ & 2.14 & 2.52 & 2.24 & .116 & 2.79 & 3.83 & 3.14 & .25 & 0,00 & sign \\
\hline 7. & Leadership skill & 2.00 & 3.11 & 2.29 & .330 & 2.11 & 3.11 & 2.51 & .29 & $\begin{array}{l}0,00 \\
8\end{array}$ & sign \\
\hline 8. & $\begin{array}{l}\text { Comunication } \\
\text { skill }\end{array}$ & 2.00 & 2.40 & 2.11 & .122 & 2.44 & 3.81 & 2.89 & .280 & 0,00 & sign \\
\hline
\end{tabular}

the midwifery practice. This is consistent with the statement by Wirawan (2013) which describes that motivation will increase the stability of work. This is where individuals who have a high work motivation will have high job satisfaction. According to David McClelland in Wirawan (1991), it was stated that motivation is a need for achievement as a state of the individual's internal drive to how much success reflects an important and valuable focus for a person. These factors can lead to job satisfaction and a willingness to work harder. If these factors exist, they will encourage more effort, but if they do not exist, then it will result in job dissatisfaction.

There is the motivation to improve the student's psychological empowerment in midwifery practice. According to Spreitzer (1995) in Utami \& Hargono (2016), psychological empowerment refers to the experience of the individual's intrinsic motivation based on the individual's orientation to their job role. Psychological empowerment is not a fixed personality attribute. It consists of the cognition formed by the work environment. Various thoughts about psychological empowerment have evolved, including in the work of Conger and Kanungo (1988), Thomas and Velthouse (1990) in Spreitzer (1995) in Utami \& Hargono (2016). Motivations can improve the student's selfefficacy in midwifery practice. This is in accordance with the statement of Victor Vroom (1964) in Wirawan (2013), which states that work motivation relates to a person's faith or beliefs about effort, so the effort involved will produce the expected output. The theory of motivation according to
Vroom is famous for the Expectancy Theory or the theory that states that the individual's perception of the possibility that an effort will lead to the achievement of a predetermined level of performance. If the expectation equals 0 (zero), then it is not possible to reach the level of performance that has been set. Expectation equals one if the person is 100 percent sure that they can achieve the specified performance. A person with self-efficacy is the belief of someone who is able to do or complete a task.

Motivation improves a student's taskcommitment in the midwifery practice. This is consistent with the motivational theory of McClellan in Wirawan (2013), which stated that motivation is the need for achievement, where the need for achievement is a need to achieve something difficult. This is often to master, manipulate, or organise physical objects, human beings, or ideas. This also involves doing so as quickly and independently as possible, to solve obstacles and to obtain a high standard, to excel yourself. It also means to increase self-esteem by implementing talents successfully. According to McClelland, someone who has a high level of achievement has three characteristics, namely: he or she have a strong desire to take personal responsibility, tend to set a medium goal when faced with difficult situations and they have a great desire to get a better level of performance.

There is the motivation to improve the student's skill in leadership in the midwifery practice. This is in accordance with McCanse 1991 in Wanarto, Guntur Budi (2014), which states that motivation is an important element 
in leadership. Wirawan (2013) explains that motivation plays an important role in leadership, which will encourage the individual motivation to act. Without motivation, people will not act, move and work well for themselves or for the organisation. Katz \& Kahn (1978) argue that leadership is an increase of the gradual influence on and above the mechanical adherence to routine organisational briefings. Leadership is the process of influencing the activities of a group that is organised towards the achievement of goals (Rauch, 1984). Many studies focused on leadership skills are discussed from various perspectives that have been conducted by the researchers. Leadership is a behaviour with a specific purpose to influence the activities of group members to achieve common goals designed to provide individual and organisational benefits (Cheok San Lam, 2012).

Communication skills are one of the parameters of soft interpersonal skills, which are a skill that is used for oneself and relates to others, cooperating with other groups, and so on. To be able to connect with other people requires a good communication process. For communication to run well by the set purpose, a person must have the ability or communication skills to do so. Based on the results of the National Association of Colleges and Employers NACE, 2002 in (Wanarto, Guntur Budi., 2014), the survey cited by Wanarto (2014) explained that there are 19 capabilities needed in the job market, which is where communication skills occupy the first necessary urgency. According to Hasibuan (2005), their study states that motivation is important because motivation is the cause, channel and support of human behaviour, so they must be willing to work hard and be enthusiastic to achieve the optimal results. Midwifery students are midwives who have the role of giving midwifery care to the client, hence needing the communication skill.

The self-leadership strategy can improve the student's sense of job satisfaction in physiological obstetric care practice. Students who have good self-leadership abilities will feel satisfied with the task of implementing the practice of physiological midwifery care. This is in line with the results of Sri Utami's (2016) study that found that self-leadership strategies can improve the midwife's job satisfaction in implementing the early detection of the growth drift of toddlers. The results of this study also support the results of Politis's research (2006) which found a direct relationship between the dimensions of the strategy focused on selfleadership behaviour with positive and statistically significant work satisfaction. The results of Yutthana's research (2010) explains that self-leadership has a direct effect on job satisfaction. This is consistent with US research studies that have found a correlation between self-leadership training and its positive impact on employee job satisfaction Neck \& Manz, 1996 (in Yutthana, 2010).

Self-leadership can improve the students' psychological empowerment in the practice of physiological obstetric care. Students with a good self-leadership strategy also have high psychological empowerment. It can be explained that each self-leadership strategy has its own role. The constructive thought patterns strategies which are associated with psychological empowerment are designed to facilitate the formation of constructive thinking and thinking in a positive way (Neck \& Manz, 2010). This is in line with the results of Sri Utami's (2016) study which explains that self-leadership strategies can improve the psychological empowerment of midwives in implementing the early detection of deviations in child growth and development. Psychological empowerment is a predictable outcome of self-leadership. Selfleadership has been established as the main mechanism to facilitate empowerment by creating perceptions of meaning, purpose, selfdirection/self-determination, and competence. Natural rewards from oneself can encourage feelings of self-direction, competence, and setting their own goals (Wirawan, 2013).

Self-leadership improves the students' self-efficacy in the practice of physiological obstetric care. Students with good selfleadership strategies have high self-efficacy. The results of this study support the results of (Utami \& Hargono, 2016), whose research states that self-leadership strategies can improve the self-efficacy of midwives in implementing the early detection of child growth drift. The results of this study also support the research conducted by Prussia et al., (1998) in (Yutthana C, 2010) in his study of 151 employees; the results obtained showed that self-leadership has a positive effect on self-efficacy. Yutthana (2010) explained that 
self-leadership has a direct effect on selfefficacy. The use of some strategic selfleadership will affect the perception of selfefficacy in a particular task.

Self-leadership can increase the task commitment of students in the midwifery care practice. Students with good self-leadership skills are committed to their high tasks as well. Commitment is the outcome of self-leadership; individuals who have strategies in selfleadership often develop a sense of belonging to their tasks and work processes. The result state that individuals can lead themselves, and that they are highly committed to their tasks and goals, both at the individual, team and organisational level, compared to individuals who cannot apply self-leadership (Wirawan, 2013)

Self-leadership increases leadership skills according to Blanchard K., Susan F, Laurie H (2006). The study explained that the earliest level of leadership is self-leadership followed by group/team leadership, organisation leadership, and the last is community/society leadership. This stage will be passed through by everyone, only the speed of each person through these stages varies. This is why there are people who, at a young age, have been able to reach a high level of leadership, but on the other hand, there is still slow development involved. Self-control is to conquer and control yourself. Those who understand others are wise; he who knows himself is intelligent. He who overpowers others is strong; he who beats himself nobly (Kaswan, 2013).

Self-leadership

increases communication skills in the midwifery practice. According to Kaswan (2013), communication skills are needed in every individual, especially for those who work in an organisation or company. A person's communication skills can make it easier for individuals to convey their bright ideas to their superiors, co-workers and subordinates. Many people can explore ideas in their thoughts or imagination, but few people can effectively communicate their thoughts and imaginations to their superiors, co-workers and subordinates. Communication skills require the ability to be able to know other people, but the most important requires the ability to know oneself. A person will be able to recognise and control themselves if the individual has good self-leadership skills.
Job satisfaction can improve task commitment; this is in line with the results of Sri Utami's (2016) study which explains that job satisfaction can improve the task of a midwife in implementing the early detection of deviations in child growth and development. (Wibowo, 2013) explained that there is a significant relationship between job satisfaction with commitment. Managers are advised to increase job satisfaction to generate higher commitment. Furthermore, higher commitment can facilitate higher productivity. The level of employee satisfaction can lead to greater commitment. Otherwise, when employees feel dissatisfied, it leads to smaller commitment, which can then affect the efforts of the employees (Lijan, 2016).

Psychological empowerment can increase the task commitment in the practice of physiological midwifery care, where students who have high psychological empowerment will have a high level of task commitment as well. Scott et al., (2011) found a strong relationship between intrinsic motivation and affective commitment, meaning that the psychological dimension of empowerment has a role in increasing affective commitment. Also, meaningful feelings, competencies and impacts tend to increase individual commitment to the organisation, as they will further enhance the ability of the individuals to express their values and interests through their work. Psychological empowerment is an intensive form of work regardless of the addition of rewards or salaries.

Psychological empowerment does not improve the students' communication skills in the midwifery practice. This is not in accordance with Rober Moss Kanter (1977) directed by Wirawan (2013), which states that empowerment empowers people to operate in unfavourable situations in an organisation. The psychological empowerment of the individual will produce positive things, namely improving the work, work processes, sharing knowledge and skills and experience.

Psychological empowerment can improve the work process. Someone in work or doing a set job process will need to interact with others. For communication to work effectively, one must have good communication skills. Mardatillah (2016) explained that communication skills are required by every individual, especially for 
those who work in an organisation or company. A person's communication skills can make it easier for individuals to convey their brilliant ideas to their boss or colleagues. With good communication skills, it will be easy to tell the ideas better so then it can be accepted. Although in this study, psychological empowerment cannot improve student skill communication, but psychological empowerment improvement is still very necessary because psychology can have a positive impact towards increasing of the other variables that can improve performance.

Psychological empowerment does not improve student skill leadership in the midwifery practice. This result is not in line with Wirawan (2013), who states that empowerment is one aspect of organisational development concerning human resource development. Empowerment means making allowing or permitting either one's own initiative or that of others. Empowerment is an interactive process based on synergism, not from zero assumptions about power. The empowerment process enlarges power in the opposite situation by merely redistributing power.

Individuals who have their own perception are highly empowered as they have a broad view of the future. Wirawan (2013) declared that empowerment aims to describe humans which have the characteristics of having views about the world and their selfconcept accurately, seeing themselves as having a benefit/use, having the ability to do something, knowing the meaning of someone sought, and progressing in life, being able to see the reason for the output and to evaluate in a compelling way. Finally, empowerment can envision the success that is capable of carrying out meaningful activities, concentrating efforts, initiating actions and flexible interactions.

Although the results of this study indicated that psychological empowerment could not improve leadership skills, for educational institutions or other organisations, it is very important to keep improving the psychology of the students or employees in the organisation. This is because many positive outcomes can be generated from good or high psychological empowerment. According to Sri Utami's (2016) research, psychological empowerment affects increasing task commitment and performance either directly or when mediated by the task commitment variable.

Self-efficacy can increase the student's commitment task in the midwifery practice. Students with high self-efficacy have high task commitment. A person with high self-efficacy will try to accomplish their tasks with various amounts of efforts; they will face obstacles that they will encounter that will not make them give up. A person with high self-efficacy will tend to set themselves goals that are more challenging, and they will be more committed to the goals of the task performed. Conversely, someone with low self-efficacy will easily give up when faced with challenges or difficulties (Bandura, 1986).

Self-efficacy does not improve the students' communication skills in the midwifery practice. Lack of access to media, unavailability to use the media, the individual's educational level, and the language used in dissemination were some of the major factors hindering effective communication to the youths (Judy, Box, \& Box, 2015). In persuasive communication, the role of the communicator is very important and influential. Thus, it must have a highperformance value. A communicator who has a high-performance value can be characterised by readiness, sincerity, trust, tranquillity, friendliness and simplicity in conveying the message. With a high self-efficacy, one will be sure to achieve the communication objectives that he has set. In this study, however, most of the students' communication skills in the practice of physiological obstetric care are mostly in the insufficient category, as well as self-efficacy also being in the insufficient category. There is an effort to improve both of these factors so that students have high-quality soft skills too because communication is one of the soft skills (Hassan et al., 2013).

Self-efficacy can not improve student skill leadership in the midwifery practice (Study et al., 2017). This is not in accordance with Agus Mulyanto (2011), who in their study stated the factors that influence teacher leadership in key learning, and that leadership qualities are superior if they have at least 8 to 9 of the best leadership qualities. One of these is always positive thinking. According to Bandura, self-efficacy is the self-perception of how well the self can function in certain situations. Bandura 1991 in (Utami, Hargono, \& Susilaningrum, 2016) stated that 
individuals who have high self-efficacy would achieve better performance because these individuals have strong motivation, clear goals, stable emotions and the ability to deliver performance in relation to a successful activity or behaviour. Individuals with high selfefficacy have the following characteristics: able to handle problems they face effectively, confident of success in dealing with problems or obstacles, problems are seen as a challenge that must be faced and not avoided, believe in the abilities they have, quickly rise from the failure they face and like to seek new situations.

In this study, it obtained results that stated that most of the respondents have moderate self-efficacy up to high, but when viewed in relation to leadership skill, most are in the less and moderate category. This shows that high self-efficacy must be accompanied by other variables to equal good leadership skills. Self-efficacy or beliefs about selfesteem can lead to overconfident attitudes. Sri Utami's (2016) attitude about overconfident is that someone's self-esteem can cause the person to become negligent to their duties and responsibilities; this causes a person's performance to no longer be maximised.

Job satisfaction improves the student's skills in communication in midwifery practice. In accordance with Frederick Herzeberg (1959) cited by Wirawan (2013), it states that the factors of job satisfaction are a good initial input to develop a model of job satisfaction. Job satisfaction and job dissatisfaction are caused by several factors or dimensions that cause satisfaction or dissatisfaction in relation to work. If the perception of the employees or individuals towards the dimensions of the cause of job satisfaction is positive, then the individual will feel satisfied, and vice versa.

Job satisfaction does not improve the students' leadership skills in the midwifery practice. The results of this study are in accordance with the results of the metaanalysis by Organ and Ryan (1985) in Wirawan (2013), who found no relationship between job satisfaction and leadership effectiveness. This is not in accordance with the opinion of Lijan P.S. (2016), who stated that job satisfaction would lead to employee commitment. One of the characteristics of effective leadership is that a leader has a high commitment both to the task and to the organisation. According to Benard M. Bass
(1990) cited by Wirawan (2013), their study suggests a list of attributes that leaders possess as a result of the research conducted between 1948 and 1970 to do with high task motivation. Someone with high job satisfaction will have a high commitment to work, innovate and be creative. These are all characteristics of an effective leader. Although in the research study, job satisfaction cannot improve leadership skills, but the two variables should still be improved in the midwifery students. Job satisfaction owned by the students must be accompanied by the commitment and high responsibility because high job satisfaction and is an important attitude in relation to leadership skills.

Task commitment improves the students skills in midwifery care. Communication skills are important in building a successful relationship within both personal and professional relationships. With good communication skills, it will produce an effective communication process. Relationships work well if built from a strong commitment to carry out promises, and how to respond to challenges. Mardatillah (2016) explained that commitment always reflects a strong sense of belief, sincerity and desire always to be willing to sincerely develop, maintain and work for the benefit of the organisation without wishing to not belong to the organisation.

Task commitment alone cannot improve the students' leadership skills in the midwifery practice. This is not in accordance with Benard M. Bass (1990) cited by Wirawan (2013), who suggests a list of attributes that leaders possess as a result of the research between 1948 and 1970 which has a firm stand against obstacles, responsibility for achieving results, and is task-oriented. These traits are characteristic of a person who commits to tasks.

\section{CONCLUSIONS}

Self-leadership supported by motivation is an important first step in shaping leadership and communication skills. Selfleadership students will be able to improve their psychological empowerment, selfefficacy, job satisfaction, task commitment, communication skills and leadership skills. Job satisfaction and high self-efficacy from the students must be followed by high task 
commitment as well. Without task commitment, self-efficacy and the job satisfaction of the students cannot improve their communication skills. Motivation strategy, self-leadership and task commitment are three important factors in improving the student's skills in communication in the midwifery care practice. The development model of self-leadership and communication skills has been built based on motivation, selfleadership and task commitment through various channels. Training using the selfleadership module can improve the ability of motivation, self-leadership strategies, job satisfaction, self-efficacy, psychological empowerment, task commitment, communication and student leadership skills.

There needs to be an important effort to improve the student's learning motivation, giving opportunities to the student to develop their ability in developing a self-leadership strategy by giving them limited autonomy according to the tasks and responsibilities of the student, giving them responsibility in every activity to finish the tasks that are targeted and in the goals of the educational institution. The next researcher is expected to research about the other variables that influence selfleadership, leadership and communication skills. The model in this study can be used as an inspiration to develop the other variables to improve the communication and leadership skills. There needs to be further research done on the parameters and other indicators of the soft skills, such as relationship skills, presentation skills, public speaking skills and stress management.

\section{REFERENCES}

Blanchard K., Susan F, Laurie H, (2006) Selfleadership and the one Minute Manager. Harper Collins: New York

Cheok San Lam, E. R. E. O. (2012). Enhancing employee outcomes: The interrelated influences of managers' emotional intelligence and leadership style. Leadership \& Organization Development Journal, Vol. 33 is, 149174.

Hassan, A., Maharoff, M., Zainal Abiddin, N., SUPER, To, S., Progress, A. R., ... Yadav, A. (2013). Soft Skills Competency Tool for Secondary Teachers in Strengthening Effective.
University of Portland, USA, 2(March), 146-155. https://doi.org/10.9790/7388-0251929

Judy, C. B., Box, P. O., \& Box, P. O. (2015). Factors that Influence Effective Communication of the Youth Enterprise Development Fund to the Youth in Kabianga Division, Kericho County, Kenya, 5(4), 172-178.

Kuswara, H., Apapun Mata Kuliah Yang diasuh Berikan Muatan soft skills Didalamnya. Availabel at: www.frieyadie.com.htm. Diakses tanggal 3 Maret 2017.

Mardatillah, A. (2016) Think and Grow Success by Soft Skill, Solo: Ary Haeko Sinergi Persada (ASP).

Puliam, M.G. (2008). Skill Employer Seek. Career Corner, Excelsior College. https://www.excelsior.edu/Excelsior_ College/ Publications/Skills Employers_Seek_16 pdf , Diakses tanggal 10 April 2015

Suryani, E.S. (2015) Peningkatan Kemampuan Soft Skills Kepemimpinan dan Komunikasi Mahasiswa Kebidanan Melalui Community Based Medical Education (CBME). Jurnal Ilmiah Kebidanan, Vol. 6 No.1, pp.23-33.

Utami, S., \& Hargono, R. (2016). Task commitment of midwife as an effort to enhance performance in early deviations detection on children growth and development based on self-leadership at working area of health agency Surabaya Indonesia, $4(4), 8-15$.

Utami, S., Hargono, R., \& Susilaningrum, R. (2016). Midwives Performance in Early Detection of Growth and Development Irregularities of Children Based on Task Commitment, 5(4), 300-305.

Wanarto, Guntur Budi., S. (2014). Soft Skill dan Perilaku Kesehatan. Surabaya: Forikes.

Wirawan. (2013). Kepemimpinan Teori, Psikologi, Perilaku Organisasi, Aplikasi dan Penelitian,. Jakarta: PT Raja Grafindo Persada.

Yutthana C. (2010). an Examination of Selfleadership Performance Mechanism model In Thai Private Organization,. The Journal of Behavioral Science, $5(1), 15-32$. 